\title{
Antibacterial Activity of Human Urine
}

\author{
Donald Kaye \\ From the Department of Medicine, The New York Hospital-Cornell Medical \\ Center, New York 10021
}

\begin{abstract}
A B S T R A C T The fate of bacteria in human urine was studied after inoculation of small numbers of Escherichia coli and other bacterial strains commonly implicated in urinary tract infection. Urine from normal individuals was often inhibitory and sometimes bactericidal for growth of these organisms. Antibacterial activity of urine was not related to lack of nutrient material as addition of broth did not decrease inhibitory activity. Antibacterial activity was correlated with osmolality, urea concentration and ammonium concentration, but not with organic acid, sodium, or potassium concentration. Between a $\mathrm{pH}$ range of 5.0-6.5 antibacterial activity of urine was greater at lower $\mathrm{pH}$. Ultrafiltration and column chromatography to remove protein did not decrease antibacterial activity.

Urea concentration was a more important determinant of antibacterial activity than osmolality or ammonium concentration. Increasing the urea of a noninhibitory urine to equal that of an inhibitory urine made the urine inhibitory. However, increasing osmolality (with sodium chloride) or increasing ammonium to equal the osmolality or ammonium of an inhibitory urine did not increase antibacterial activity. Similarly, dialysis to decrease osmolality or ammonium but preserve urea did not decrease inhibitory activity. Decreasing urea with preservation of ammonium and osmolality decreased antibacterial activity. Removal of ammonium with an ion exchanger did not decrease
\end{abstract}

This work was presented in part at the 59th Annual Meeting of the American Society for Clinical Investigation, Inc., 1 May 1967, Atlantic City, N. J. (1).

Dr. Kaye is an Associate Professor of Medicine, Cornell University Medical College, New York 10021.

Received for publication 23 April 1968. antibacterial activity, whereas conversion of urea to ammonium with urease and subsequent removal of the ammonium decreased antibacterial activity.

Urine collected from volunteers after ingestion of urea demonstrated a marked increase in antibacterial activity, as compared with urine collected before ingestion of urea.

\section{INTRODUCTION}

It has commonly been stated that urine is an excellent culture medium for the bacteria that cause urinary tract infection (2-4). For example, Kass (2) stated that "even without added glucose, urine generally supports multiplication of the usual pathogens of the urinary tract about as well as does nutrient broth, and variations in $\mathrm{pH}$ and specific gravity within physiologic ranges exert but slight effects on bacterial multiplication."

However, Davis and Hain (5) in 1918 demonstrated that dog urine was bactericidal for Gramnegative bacteria. Subsequently, Clark (6) and Helmholz (7) found that urine of patients receiving ketogenic diets demonstrated antibacterial activity which they felt was related to the presence of organic acids. Kass and Ziai (8) described a substance found in urine of some normal individuals that was bacteriostatic at $\mathrm{pH} 5.0$ for Escherichia coli. This inhibitor was nonvolatile, alcohol-soluble and ether-insoluble and was thought to be a weakly ionizable acid. Bodel, Cotran, and Kass (9) fed large amounts of cranberry juice to patients (which results in increased urinary excretion of hippuric acid, an organic acid) and demonstrated that the urine inhibited bacterial growth at low $\mathrm{pH}$.

The effect of $\mathrm{pH}$ on multiplication of bacteria 
in urine has been investigated by others (10-15). Shohl and Janney (10) and Asscher et al. (15) found that optimal growth of $E$. coli in urine occurred between $\mathrm{pH} 6.0$ and 7.0. These investigators and others (11-13) demonstrated that inhibition of growth occurred at $\mathrm{pH} 5.0$ and below. Kaitz (14) and Asscher et al. (15) found that the inhibitory effect at $\mathrm{pH} 5.0$ was most marked at an osmolality above $600 \mathrm{mOsm} / \mathrm{kg}$ of water. This effect was thought by Kaitz to be in part related to a higher concentration of undissociated organic acids in concentrated urine. Fe also stated that he observed inhibition of growth in concentrated urines that was not $\mathrm{pH}$-dependent and which he felt might be due to urea.

Neter and Clark (16) demonstrated that urea added to urine in concentrations ranging from 3.1 to $6.3 \mathrm{~g} / 100 \mathrm{ml}$ markedly increased antibacterial activity. Jackson and Grieble (17) found that addition of $0.5 \mathrm{~g} / 100 \mathrm{ml}$ of urea to urine did not inhibit multiplication of bacteria.

In general these studies demonstrated that urine at $\mathrm{pH} 5.0$ and below is often inhibitory for growth of microorganisms. With this exception, there is no convincing evidence in these studies that urine from normal individuals is inhibitory for growth of $E$. coli and other bacteria that cause urinary tract infection. The methodology used in the different studies varied widely: in some, the bacterial inoculum was small (i.e., less than 1000 bacteria $/ \mathrm{ml}$ ) and in others the inoculum was large; there was considerable variation in the time of incubation; in some of the studies, only one specimen (or one pool) of urine was studied and in others only one strain of bacteria was evaluated. None of the studies made an intensive effort to elucidate the factors that may contribute to inhibitory activity of urine and to determine the relative importance of each factor.

When bacteria invade the lower urinary tract, it seems likely that the inoculum would be small. Furthermore, the outcome of such an invasion is probably more related to the initial rate of multiplication of the bacteria than to events occurring after many hours. The present study was undertaken to determine the fate of bacteria in human urine after inoculation of small numbers of microorganisms and to evaluate the effect of variations in $\mathrm{pH}$, osmolality, urea, ammonium, and organic acids on the rate of bacterial multiplication.

\section{METHODS}

Bacteria. 16 strains of Escherichia coli, and one strain each of Aerobacter aerogenes, Pseudomonas aeruginosa, Proteus mirabilis, enterococcus, Staphylococcus aureus, and Staphylococcus albus were studied. E. coli strains 1-8 and the strains of $A$. aerogenes, $P$. aeruginosa, $P$. mirabilis, and enterococcus were isolated from urine of patients with urinary tract infections. E. coli strains 9-16 were isolated from stool cultures of different patients. The strains of $S$. aureus and $S$. albus were isolated from nasal or pharyngeal cultures. The serotypes of the $E$. coli strains were: strain 1 , nontypable; strain 2,025 ; strain 3 , $054 / \mathrm{H}-14$; strain $4,017 / 066 / 077$; strain $5,025 / \mathrm{H}-1 / \mathrm{H}-12$; strain 6 , nontypable/H-14; strain 7,0139 ; strain 8,01 ; strain 9, $018 \mathrm{ab} / 018 \mathrm{ac}$; strain $10,08 / \mathrm{H}-9$; strain 11 , $08 / \mathrm{H}-9$; strain $12,06 / \mathrm{H}-1 / \mathrm{H}-12$; strain $13,021 / \mathrm{H}-4$ / $\mathrm{H}-17$; strain 14, 0111B4; strain 15, $018 \mathrm{ab} / 018 \mathrm{ac} / 023$ / $\mathrm{H}-7$; and strain 16, 0128B12.

Stock cultures were maintained by storing aliquots of an $18 \mathrm{hr}$ culture in standard strength trypticase soy broth (i.e., $3 \mathrm{~g}$ of trypticase soy broth powder $/ 100 \mathrm{ml}$ of distilled water) (Baltimore Biological Laboratory, Baltimore, Md.) at $-20^{\circ} \mathrm{C}$.

Urine samples. Midstream urine from 11 normal subjects was studied. Subjects 1-5 were males 25-35 yr of age; subjects $6-8$ were females $21-26$ yr of age; subjects 9 and 10 were males, ages 5 and 6 yrs; and subject 11 was a $5 \mathrm{yr}$ old girl. None of the subjects were receiving antimicrobial agents and none were receiving special diets. None of the females were taking birth control pills. Fluid restriction was not employed. All urines were refrigerated until filtration the same day.

The urine specimens were sterilized by filtration through a $0.45 \mu$ filter (Millipore Filter Corporation, Bedford, Mass.) and then divided in tubes in 5-ml aliquots. Tubes of urine that were not used in experiments the same day were stored at $-20^{\circ} \mathrm{C}$. Determinations were made of $\mathrm{pH}$ (Beckman $\mathrm{pH}$ meter, model G, Beckman Instruments Inc., Fullerton, Calif.), osmolality (Fiske Osmometer, model G-12, Fiske Associates, Inc., Uxbridge, Mass.), urea and ammonium nitrogen (UN-Test, Hyland Laboratories, Los Angeles, Calif.), sodium and potassium (Flame photometer, model 143, Instrumentation Laboratory, Inc., Boston, Mass.), and organic acid concentrations.

A modification of the method of Van Slyke and Palmer (18) was used for determination of organic acids. 20 $\mathrm{mg} / \mathrm{ml}$ of calcium hydroxide was added to up to $50 \mathrm{ml}$ of urine. The urine was then periodically agitated over a $20 \mathrm{~min}$ period, filtered through filter paper, and adjusted to $\mathrm{pH}$ 7.0. An aliquot of filtrate was titrated from $\mathrm{pH}$ 7.0 to $\mathrm{pH} 2.5$ with $0.1 \mathrm{~N}$ hydrochloric acid. An equal volume of water was titrated from $\mathrm{pH} 7.0$ to $\mathrm{pH} 2.5$ with $0.1 \mathrm{~N}$ hydrochloric acid. The number of milliliters of hydrochloric acid required to titrate the urine, minus the number of milliliters required to titrate the water, divided by 10 , was the number of milliequivalents of organic acid in the titrated aliquot of urine.

The $\mathrm{pH}$, osmolality, urea, ammonium, sodium, potas- 
sium, and organic acid concentrations were not altered by filtration.

Experiments. Growth characteristics of the bacteria were studied in the urines and in broth controls. Inocula were prepared by subculturing an aliquot of the stock culture in trypticase soy broth. After incubation at $37^{\circ} \mathrm{C}$ for $18 \mathrm{hr}$, dilutions were prepared in trypticase soy broth or sterile distilled water. For each experiment $0.1 \mathrm{ml}$ of one of the bacterial dilutions was inoculated in $1 \mathrm{ml}$ portions of urine and in $1 \mathrm{ml}$ of trypticase soy broth or water. In some experiments 5-ml portions of urine or trypticase soy broth were used. The broth, water, and urine specimens were heated to $37^{\circ} \mathrm{C}$ before addition of the bacterial inoculum. (In experiments where urine was treated in various ways, or where solutions other than urine were studied, specimens were sterilized before addition of the bacterial inoculum by filtration through a $0.45 \mu$ filter).

Immediately after addition of the bacterial inoculum and again after 3,6 , and $24 \mathrm{hr}$ of incubation at $37^{\circ} \mathrm{C}$, aliquots were removed from each specimen for determination of numbers of bacteria present.

Bacterial enumeration. The numbers of bacteria in a specimen were determined by plating $0.1 \mathrm{ml}$ of each specimen and making serial 100 -fold dilutions in distilled water and plating 1 and $0.1 \mathrm{ml}$ aliquots of each dilution in trypticase soy agar pour plates. In experiments with $P$. mirabilis, the agar was allowed to harden and a second layer poured to prevent swarming. The total number of viable bacteria per milliliter was calculated from colony counts after incubation of the plates for $24 \mathrm{hr}$ at $37^{\circ} \mathrm{C}$. In each experiment representative colonies were identified to assure identity with the microorganism inoculated.

\section{RESULTS}

Multiplication of $E$. coli strains in urine

Fig. 1 shows the results of a typical experiment in which $E$. coli strain 13 suspended in $0.1 \mathrm{ml}$ of sterile distilled water was incubated in 5-ml of trypticase soy broth and in 5-ml of first voided morning urine from subjects 1,2 , and 4 . The inoculum was 40 colony-forming units $/ \mathrm{ml}$. Multiplication of bacteria did not occur in urine from subject 1 and aliquots of this urine were sterile after 6 and $24 \mathrm{hr}$ of incubation. Although bacteria did eventually multiply in urine from subjects 2 and 4, multiplication was much slower in the urines than in broth. There was no increase in titer after $3 \mathrm{hr}$ of incubation in these urines and only a 10 -fold increase after $6 \mathrm{hr}$ of incubation. This compares with 10 - and 1000 -fold increases in the number of bacteria in the broth after 3 and $6 \mathrm{hr}$ of incubation. After $24 \mathrm{hr}$ of incubation the urines contained less than $1 \%$ of the number of bacteria in the trypticase soy broth.

Similar results were obtained with 10 other strains of $E$. coli. In these experiments $3-40$ colony-forming units $/ \mathrm{ml}$ of each $E$. coli strain were inoculated into the same first-voided morning urines from subjects 1,2 , and 4 . After $3 \mathrm{hr}$ of incubation in trypticase soy broth there was at least a 10 -fold $(1 \mathrm{log})$ increase in the titer of all strains. In contrast, after $3 \mathrm{hr}$ of incubation in each of the three urines, there was no increase in the titer of five of the $E$. coli strains and only small increases in titers of the other five strains. Fig. 2 demonstrates the results after $6 \mathrm{hr}$ of incubation for strain 13 and the other 10 strains. The increase in numbers of organisms is expressed as $\log$ increase $6 \mathrm{hr}$ incubation and is calculated by

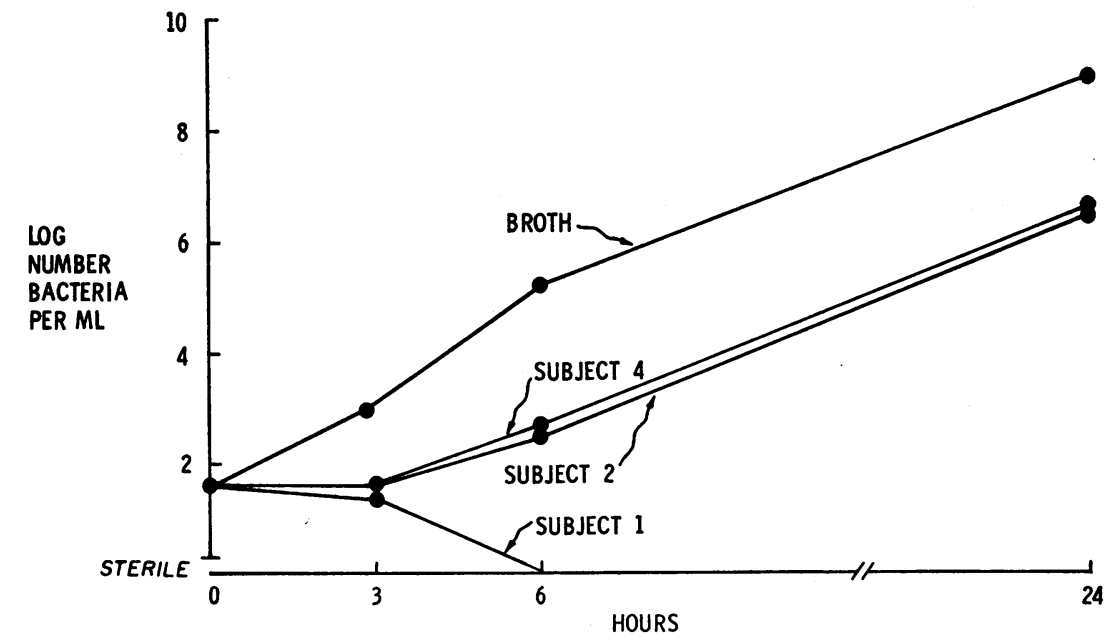

Figure 1 Fate of $E$. coli strain 13 in urine from Subjects 1, 2, and 4 and in trypticase soy broth after inoculation with 40 colony-forming units $/ \mathrm{ml}$. 


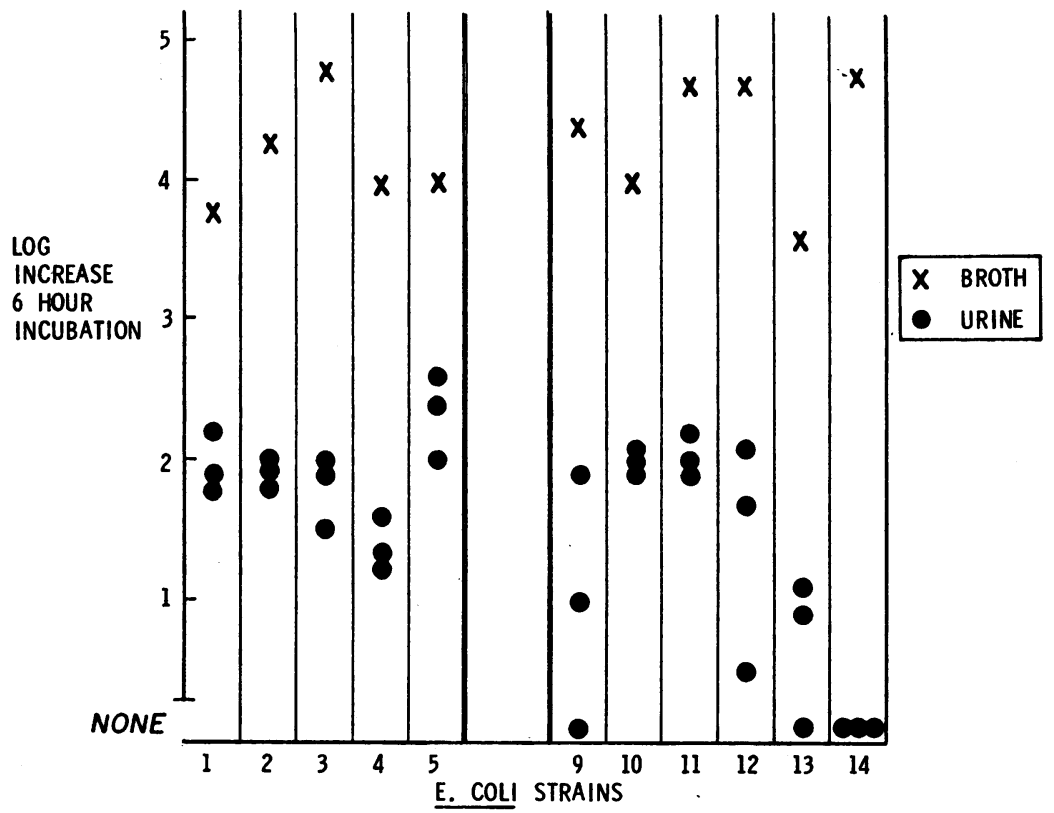

FIGURE 2 Increase in numbers of $11 \mathrm{E}$. coli strains in urine from subjects 1,2 , and 4 and in trypticase soy broth after $6 \mathrm{hr}$ of incubation. The inocula ranged from 3 to 40 colony-forming units $/ \mathrm{ml}$.

subtracting $\log _{10}$ of the inoculum per milliliter from $\log _{10}$ of the number of bacteria per milliliter after $6 \mathrm{hr}$ of incubation. All of the bacterial strains multiplied faster and grew to higher titers in trypticase soy broth than in urine. Strain 14 did not multiply in any of the three urines and the urines were sterile after 6 and $24 \mathrm{hr}$ of incubation. Similarly, urine from subject 2 was bactericidal for strain 9 and (as shown in Fig. 1) urine from subject 1 was bactericidal for strain 13 .

Urine that was bactericidal for small inocula (i.e., less than $10^{2}$ bacteria $/ \mathrm{ml}$ ) of an $E$. coli strain was usually inhibitory but rarely bactericidal for larger inocula. For example multiplication of different inocula of $E$. coli strain 13 was studied in a second voided morning urine from subject 4 . The urine was bactericidal for an inoculum of $10 / \mathrm{ml}$. With inocula of $10^{3}$ or $10^{5} / \mathrm{ml}$ there was a lag phase of $6 \mathrm{hr}$ followed by multiplication of bacteria. However the titer achieved after $24 \mathrm{hr}$ of incubation was less than $1 \%$ of the titer achieved in trypticase soy broth.

Urine specimens were obtained from subjects 1 , 2 , and 4 at different times of the day over a period of weeks (e.g., first and second voided morning specimens and mid and late afternoon specimens). The growth of E. coli strains 13 and 14 was studied in each of these specimens and compared with growth in trypticase soy broth. In general, most of the urine specimens from an individual were about equally inhibitory regardless of the time of day voided. Most of the specimens were bactericidal for $E$. coli strain 14 and some were bactericidal for strain 13 .

Growth of $E$ coli strain 14 was studied in urine from subjects 1 and 2 collected before (second voided morning specimens) and during a diuresis induced by drinking large quantitites of water. Before diuresis the urines contained 1117 and $1100 \mathrm{mOsm} / \mathrm{kg}$ of water, respectively, and during diuresis the concentrations were 495 and 225 $\mathrm{mOsm} / \mathrm{kg}$ of water, respectively. Urine from both subjects collected before diuresis was bactericidal for E. coli strain 14, whereas urine obtained during diuresis supported growth of this strain almost as well as trypticase soy broth.

A series of experiments was performed to determine and compare growth characteristics of 16 strains of $E$. coli in first voided morning urine from nine of the subjects (subjects 1-3, 6-11). A sample of the same urine specimen from each subject was tested against each of the $16 \mathrm{E}$. coli 
strains. In these experiments, to eliminate the possibility that poor bacterial growth in urine was related to lack of nutrient material, the $E$. coli strains were suspended in trypticase soy broth. $0.1 \mathrm{ml}$ of trypticase soy broth containing the $E$. coli strain was added to $1 \mathrm{ml}$ of urine from each of the subjects and to $1 \mathrm{ml}$ of sterile distilled water. The inocula were $10^{2}-10^{3}$ colony-forming units $/ \mathrm{ml}$. Each urine and water specimen contained a final concentration of $9 \%$ standard strength trypticase soy broth (i.e., $0.27 \mathrm{~g}$ of trypticase soy broth powder $/ 100 \mathrm{ml}$ of water. This concentration of broth is sufficient to result in rapid growth of all of the bacterial strains studied. Fig. 3 shows results of experiments with the 16 strains of $E$. coli. The bacteria usually multiplied faster and grew to higher titers in water containing trypticase soy broth than in urine. All nine urines were inhibitory for some of the E. coli strains and five of the urine specimens were inhibitory for all of the strains. Six of the urines were bactericidal for one or more $E$. coli strains.

Although no one urine was uniformly the best or poorest medium for growth of all of the E. coli strains, there was a tendency for a particular urine to be a relatively good or relatively poor growth medium. For example, most of the strains grew relatively well in urine from subjects 10 and 11 and relatively poorly in urine from subjects 2 and 6. Fig. 4 shows the results of the experiments in Fig. 3 charted to show the increase in numbers of each of the 16 strains of $E$. coli in urine from subjects 6 and 11. Multiplication of most of the strains was only slightly inhibited in urine from subject 11 , as compared with multiplication in water; in contrast, growth of most of the strains was markedly inhibited in urine from subject 6 .

In order to arrange urines from the nine subjects in order of inhibitory activity against the 16 strains of E. coli, graphs similar to Fig. 4 were constructed for each urine sample. The log increase of the median organism on each graph after $6 \mathrm{hr}$ incubation was used as the "score" for that urine (e.g., in Fig. 4 the median log increases for subjects 6 and 11 after $6 \mathrm{hr}$ of incubation are 1.7 and 3.4 , respectively). Table I lists the median log increase after $6 \mathrm{hr}$ incubation in each urine and also lists the $\mathrm{pH}$, osmolality, urea nitrogen, ammonium nitrogen, and milliequivalents of sodium, potassium, and organic acids of each of the nine

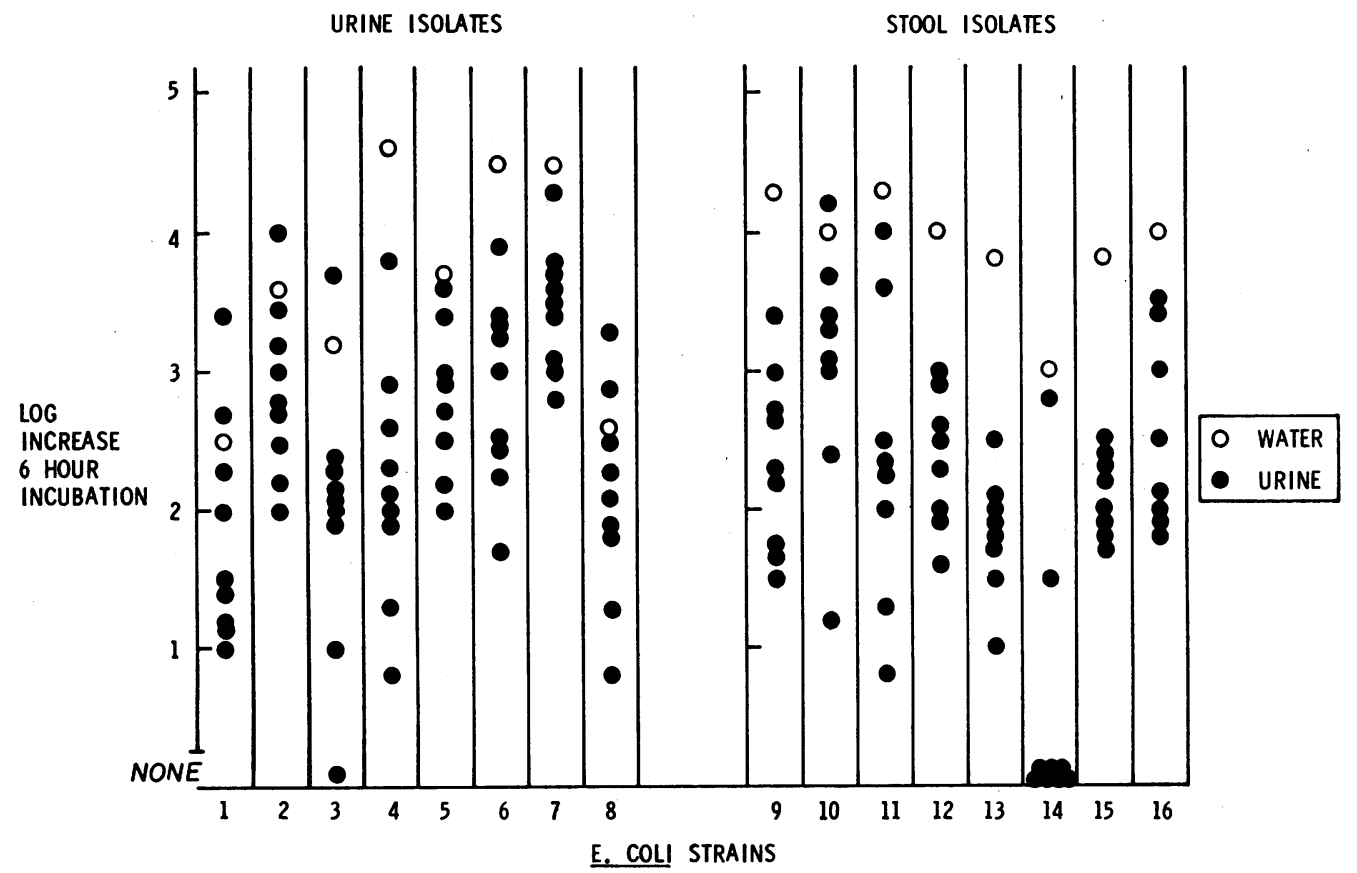

FigURE 3 Increase in numbers of $16 \mathrm{E}$. coli strains in urine from subjects $1-3,6-10$, and 11 and in water after inoculation with $10^{2}-10^{3}$ colony-forming units $/ \mathrm{ml}$. The inocula were suspended in trypticase soy broth. 


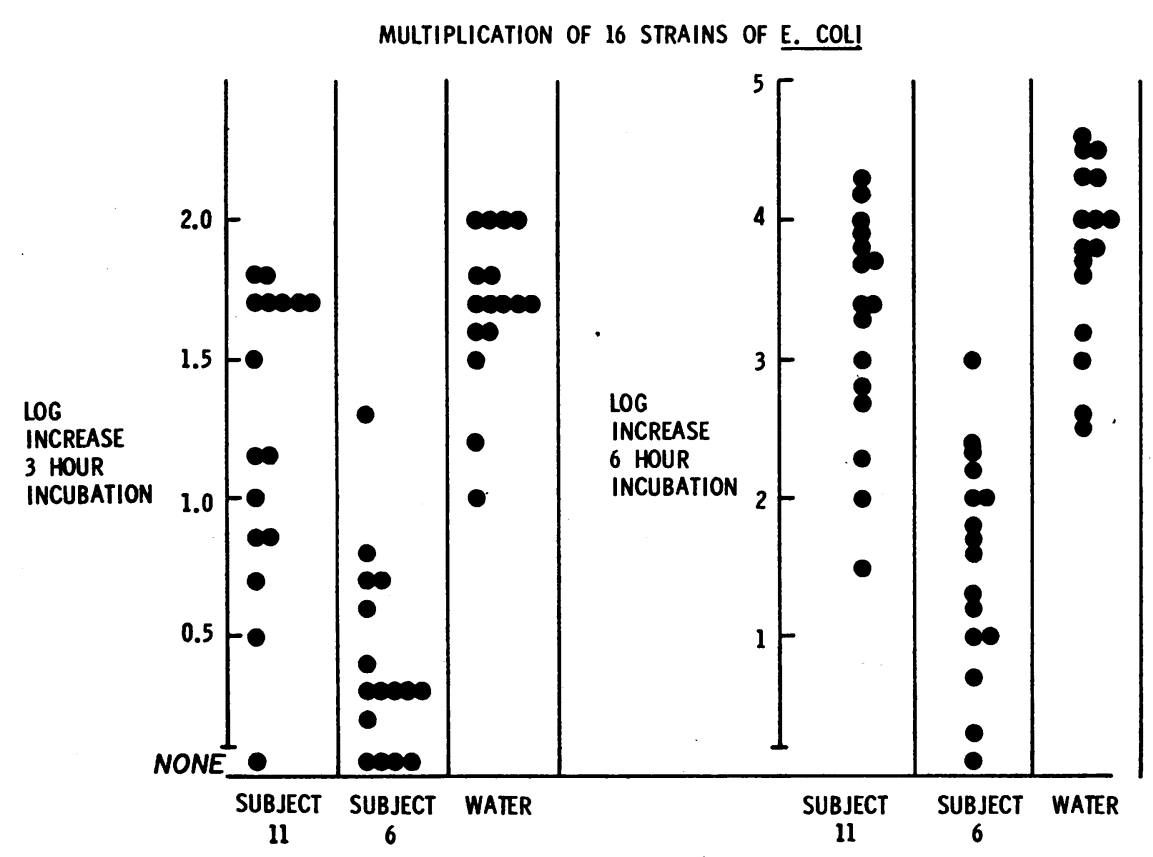

FIGURE 4 Increase in numbers of $E$. coli in urine from subjects 6 and 11 and in water after inoculation with $10^{2}-10^{3}$ colony-forming units $/ \mathrm{ml}$. The inoculum was suspended in trypticase soy broth. The data are derived from Fig. 3.

urines. As can be seen from Table I, there was a lation between antibacterial activity and $\mathrm{pH}$, sohigh correlation between antibacterial activity of dium, potassium and organic acids was poor. The urine and high osmolality, urea nitrogen and ammonium nitrogen. The correlation coefficients were : $r=0.90$ for osmolality $(P<0.01) ; r=$ 0.69 for urea nitrogen $(P<0.05)$; and $r=0.69$ for ammonium nitrogen $(P<0.05)$. The corre- lation between antibacterial activity and $\mathrm{pH}$ in

TABLE I

Growth-Supporting Quality, pH, Osmolality, Urea Nitrogen, Ammonium Nitrogen, Sodium, Potassium, and Organic Acids of Nine Urine Samples

\begin{tabular}{|c|c|c|c|c|c|c|c|c|}
\hline Subject & $\begin{array}{l}\text { Median } \\
\text { log in- } \\
\text { crease } \\
\text { after } 6 \\
\text { hr incu- } \\
\text { bation }\end{array}$ & $\mathrm{pH}$ & Osmolality & $\begin{array}{c}\text { Urea } \\
\text { nitrogen }\end{array}$ & $\underset{\text { nitrogen }}{\text { Ammonium }}$ & Sodium & Potassium & $\begin{array}{c}\text { Organic } \\
\text { acids }\end{array}$ \\
\hline & & & $\begin{array}{l}\mathrm{mOsm} / \mathrm{kg} \\
\text { of water }\end{array}$ & $\mathrm{g} / 100 \mathrm{ml}$ & $\mathrm{g} / 100 \mathrm{ml}$ & $\begin{array}{c}m E q \\
\text { liter }\end{array}$ & $\begin{array}{c}m E q / \\
\text { liter }\end{array}$ & $\begin{array}{c}m E q / \\
\text { liter }\end{array}$ \\
\hline 6 & 1.7 & 5.5 & 1200 & 1.9 & 0.10 & 88 & 98 & 38 \\
\hline 2 & 1.8 & 5.5 & 1033 & 1.3 & 0.07 & 220 & 63 & 25 \\
\hline 9 & 2.0 & 5.0 & 1157 & 2.0 & 0.08 & 153 & 23 & 25 \\
\hline 1 & 2.0 & 5.5 & 1175 & 1.7 & 0.07 & 160 & 49 & 26 \\
\hline 7 & 2.3 & 5.3 & 1045 & 1.4 & 0.10 & 138 & 52 & 22 \\
\hline 8 & 2.3 & 5.4 & 1060 & 1.5 & 0.04 & 144 & 75 & 23 \\
\hline 3 & 2.6 & 5.0 & 745 & 1.0 & 0.02 & 67 & 40 & 50 \\
\hline 10 & 3.0 & 5.5 & 810 & 1.3 & 0.06 & 71 & 61 & 26 \\
\hline 11 & 3.4 & 5.5 & 677 & 1.1 & 0.02 & 93 & 26 & 35 \\
\hline
\end{tabular}


these experiments (in contrast to subsequent experiments) was probably related to the narrow $\mathrm{pH}$ range of the urines (5.0-5.5).

Multiplication of bacteria other than E. coli in urine

Studies were also done with strains of $A$. aerogenes, $P$. aeruginosa, $P$. mirabilis, enterococcus, $S$. aureus, and $S$. albus. In these experiments 0.1 $\mathrm{ml}$ of trypticase soy broth containing each bacterial species was added to $1 \mathrm{ml}$ of sterile distilled water and to $1 \mathrm{ml}$ of each of the urine specimens listed in Table I. The final inoculum was $10-10^{3}$ colony-forming units $/ \mathrm{ml}$. Each urine and water specimen contained a final concentration of $9 \%$ standard strength trypticase soy broth (i.e., 0.27 $\mathrm{g}$ of trypticase soy broth powder $/ 100 \mathrm{ml}$ of water). This concentration of broth is sufficient to result in growth of all of the bacterial strains studied. Multiplication of all strains was inhibited in most of the urines, as compared with water.

Fig. 5 shows the $\log$ increase of bacteria in urine or water after $6 \mathrm{hr}$ of incubation at $37^{\circ} \mathrm{C}$. During the 1 st $6 \mathrm{hr}$ the strain of $P$. aeruginosa, the two strains of staphylococcus, and the strain of enterococcus did not multiply in some of the urines. After $24 \mathrm{hr}$ of incubation these microorganisms multiplied to relatively high titers in most urines. In general, the urines that were most inhibitory for these strains of bacteria (i.e., $A$. aerogenes, $P$. aeruginosa, $P$. mirabilis, enterococcus, and staphylococcus) were also the most inhibitory for the strains of $E$. coli.

Investigations into factors in urine inhibitory for $E$. coli

Effect of dilution of urine. The inhibitory activity of urine was decreased after dilution of the urine in sterile distilled water. In these experiments $0.1 \mathrm{ml}$ of sterile water containing $E$. coli strain 13 or 14 was added to $5-\mathrm{ml}$ of trypticase soy broth, $5-\mathrm{ml}$ of first voided morning urine from subject 4 , and 5-ml each of $1: 2$ and $1: 4$ dilutions of the urine in sterile water. The resultant inocula were 20-40 colony-forming units $/ \mathrm{ml}$. The undiluted urine was bactericidal for both strains; multiplication of bacteria was somewhat inhibited in the urines diluted 1:2 in water; and multiplication of bacteria in the urines diluted $1: 4$ in water approximated the rate of multiplication in broth.

Effect of modification of $p H$. The inhibitory activity of urine tended to decrease as the $\mathrm{pH}$ of the urine was adjusted above $\mathrm{pH} 6.0$, but was still demonstrable even at $\mathrm{pH}$ 6.5. For example, Fig. 6 shows an experiment in which the $\mathrm{pH}$ of $1 \mathrm{ml}$ samples of second voided morning urine ( $\mathrm{pH}$ 5.6) from subject 1 was adjusted to $\mathrm{pH} 5.0$, $5.5,6.0$, or 6.5 by addition of less than $0.01 \mathrm{ml}$ of

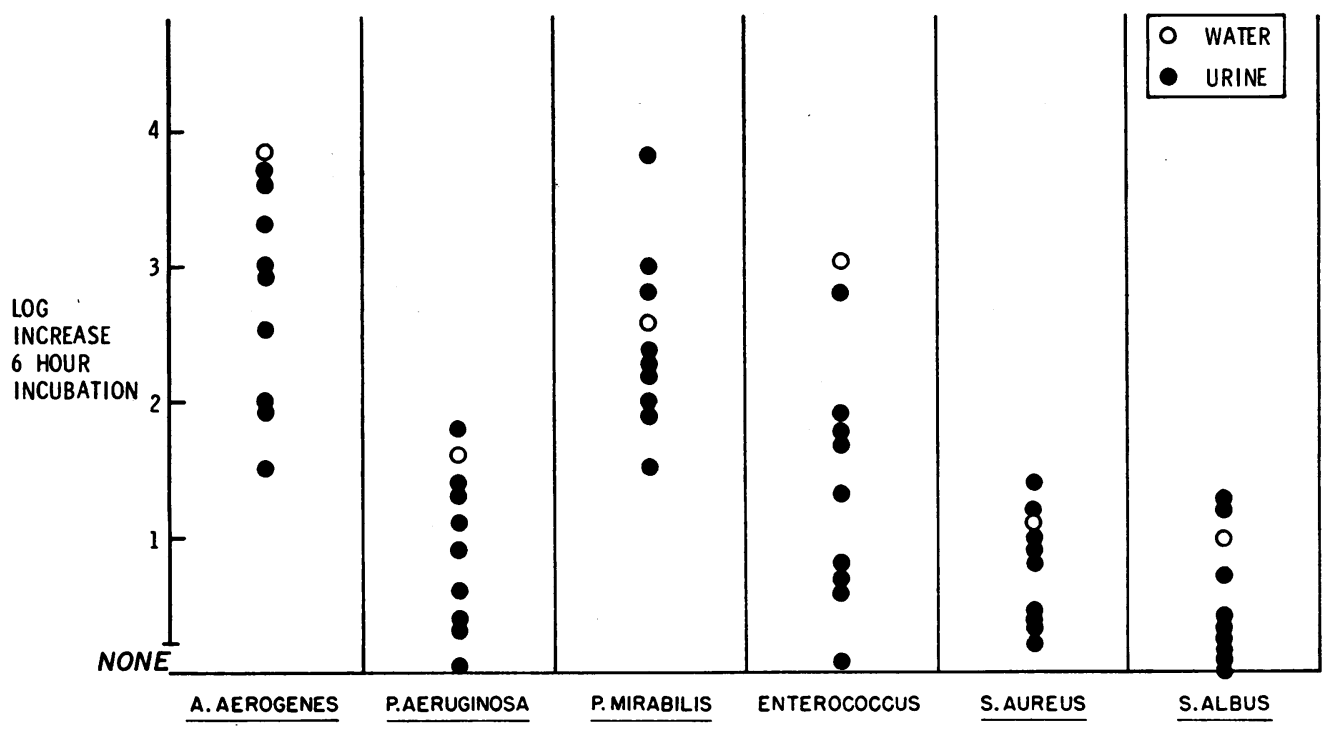

FIGURE 5 Increase in numbers of strains of $A$. aerogenes, $P$. aeruginosa, $P$. mirabilis, enterococcus, $S$. aureus, and $S$. albus in urine from subjects $1-3,6-10$, and 11 and in water after inoculation with $10-10^{3}$ colony-forming units $/ \mathrm{ml}$. The inocula were suspended in trypticase soy broth. 


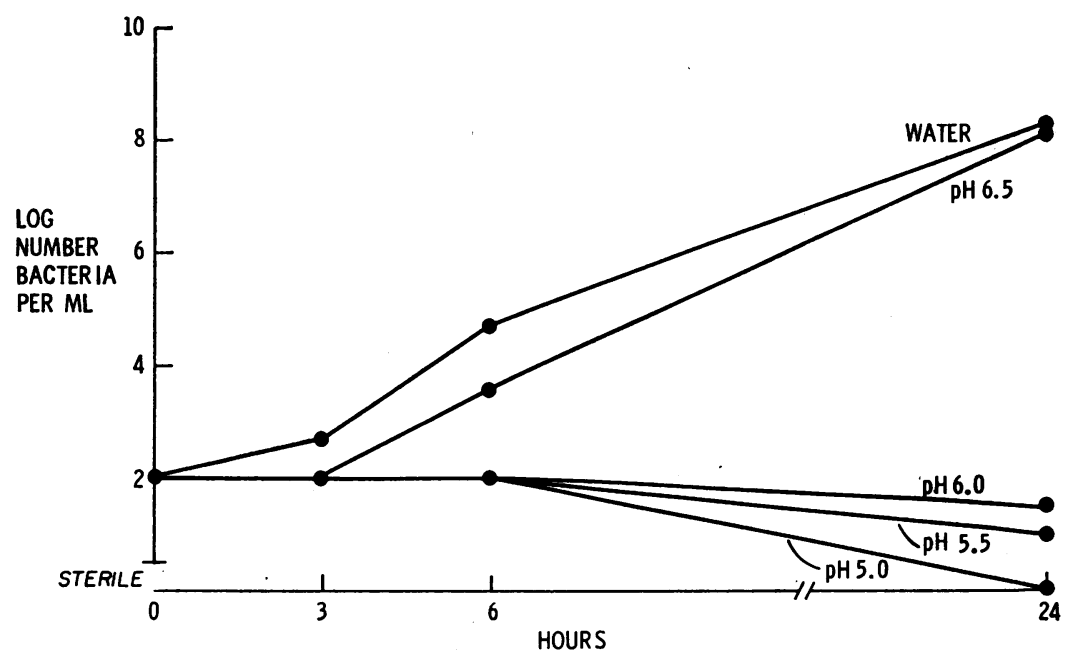

FIGURE 6 Fate of $E$. coli strain 14 in water and in urine from Subject 1 at $\mathrm{pH} 5.0,5.5,6.0$, and 6.5 after inoculation of $10^{2}$ colony-forming units $/ \mathrm{ml}$. The inoculum was suspended in trypticase soy broth.

$1 \mathrm{~N}$ hydrochloric acid or sodium hydroxide. $E$. coli strain 14 in $0.1 \mathrm{ml}$ of trypticase soy broth was added to each urine sample and to $1.0 \mathrm{ml}$ of water; the inoculum was $10^{2}$ colony-forming units $/ \mathrm{ml}$. As shown in Fig. 6 the urines at $\mathrm{pH}$ 5.0, 5.5, and 6.0 were markedly inhibitory or bactericidal for the E. coli strain. Although multiplication eventually occurred at $\mathrm{pH} 6.5$, growth after 3 and $6 \mathrm{hr}$ of incubation was inhibited, as compared with growth in water.

Extraction with ethyl alcohol and ethyl ether. Tubes containing 5-ml aliquots of urine from subject 1 (which was bactericidal for small inocula of $E$. coli strains 13 and 14 ) were heated at $100^{\circ} \mathrm{C}$ until only dry powder remained. 5 -ml of water was added to one tube. To each of two other tubes $20-\mathrm{ml}$ of absolute ethyl alcohol or 20-ml of ethyl ether was added. The powder was resuspended and then the tubes centrifuged at $2000 \mathrm{~g}$ for $20 \mathrm{~min}$. The supernates were removed and the tubes allowed to dry. 5-ml of water was then added to each of the two tubes. Extraction with ethyl alcohol removed the urea and ammonium, and proportionately decreased the osmolality but did not change the $\mathrm{pH}$. Extraction with ethyl ether did not affect $\mathrm{pH}$, urea, ammonium, or osmolality. Extraction with either ethyl alcohol or ethyl ether decreased the organic acid content by $50 \%$. The evaporated and reconstituted urine $(\mathrm{pH}$, urea, ammonium, osmolality, and organic acids unchanged) and the urine that had been extracted with ethyl ether were still bactericidal for $E$. coli strains 13 and 14 . The urine extracted with ethyl alcohol was not inhibitory for either strain.

Effect of procedures designed to remove or inactivate proteins. Urine was absorbed with heatkilled $E$. coli to remove antibody that might be present. Absorption did not remove the antibacterial activity of that urine for the same or different E. coli strains. In these experiments a vaccine was prepared from $E$. coli strain 13 by washing surface growth from trypticase soy agar slants with sterile distilled water. The suspension of $E$. coli was washed in water and then concentrated to $2 \times 10^{10}$ colony-forming units $/ \mathrm{ml}$. The bacteria were killed by exposure to $60^{\circ} \mathrm{C}$ for $1 \mathrm{hr}$. Second voided morning urine from subject 4 (which was bactericidal for small inocula of $E$. coli strains 9 and 13) was absorbed with the vaccine by adding 3-ml of urine to the sediment from 5-ml of vaccine. After incubation for $1 \mathrm{hr}$ at $37^{\circ} \mathrm{C}$ and $18 \mathrm{hr}$ at $20^{\circ} \mathrm{C}$ the urine was filtered through a $0.45 \mu$ filter to remove the bacteria. The filtered urine was still bactericidal for small inocula of $E$. coli strains 9 and 13 .

The inhibitory activity of urine was not decreased by heating. In these experiments, the fate of $E$. coli strains 13 and 14 in inocula of $10^{2}-$ $10^{3} / \mathrm{ml}$ was observed in first voided morning urine from subjects 1 and 2 after the urine had been treated by each of the following procedures: (1) incubating at $56^{\circ} \mathrm{C}$ for $30 \mathrm{~min}$; (2) boiling for 10 $\min$ and reconstituting to the original volume with 
sterile distilled water; or (3) evaporating at $100^{\circ} \mathrm{C}$ and then reconstituting with distilled water. None of these procedures significantly altered the antibacterial activity of the urine.

To remove large molecules, urine was ultrafiltered by passage through a collodion membrane with a pore size of less than $5 \mathrm{~m} \mu$. In other experiments urine was passed through a dextran (Sephadex G-10) column (Pharmacia Laboratories Inc., Piscataway, N. J.) prepared with distilled water at $4^{\circ} \mathrm{C}$. Under these conditions molecules with a mol wt over 700 pass rapidly through the column; urea and electrolytes are held back and can subsequently be eluted with distilled water. The protein-containing and the protein-free portions of the urine were concentrated by lyophilization. The protein-containing portion was essentially ureaand electrolyte-free and the protein-free portion contained essentially all of the urea and electrolytes. The protein-containing portion of the urine was adjusted to a protein concentration equal to the original urine and the protein-free portion was adjusted to the original urea concentration and osmolality. Urine from subject 1 containing $7 \mathrm{mg}$ of protein $/ 100 \mathrm{ml}$ that was bactericidal for small inocula of $E$. coli strains 13 and 14 was ultrafiltered or passed through a Sephadex G-10 column as described. Bactericidal activity was retained after ultrafiltration. Bactericidal activity was present in the protein-free portion of the urine collected from the column, but was not present in the protein-containing portion.

Effect of modifying urea or ammonium concentration or osmolality. Experiments were undertaken to determine the contribution of urea, ammonium, and osmolality to the antibacterial activity of urine. In these studies, urine that was not inhibitory for $E$. coli strain 13 was supplemented with either urea (Fisher Scientific Co., New York), ammonium chloride, or sodium chloride to raise the urea concentration, ammonium concentration, or osmolality to equal that of urine that was bactericidal for $E$. coli strain 13 . These experiments demonstrated that supplementation with urea markedly increased the inhibitory quality of the urine; supplementation with ammonium chloride or sodium chloride did not have much effect. The urines used were those listed in Table I. Urine from subject 11 (urea nitrogen concentration of $1.1 \mathrm{~g} / 100 \mathrm{ml}$, ammonium nitrogen of
$0.02 \mathrm{~g} / 100 \mathrm{ml}$, and osmolality of $677 \mathrm{mOsm} / \mathrm{kg}$ of water) was supplemented with urea to a urea nitrogen concentration of $2.0 \mathrm{~g} / 100 \mathrm{ml}$ (equivalent to that of subject 9; see Table I). A second aliquot of urine from subject 11 was supplemented with ammonium chloride to an ammonium nitrogen concentration of $0.08 \mathrm{~g} / 100 \mathrm{ml}$, and a third aliquot was supplemented with sodium chloride to increase the osmolality to $1157 \mathrm{mOsm} / \mathrm{kg}$ (equivalent to that of subject 9; see Table I). E. coli strain 13 in $0.1 \mathrm{ml}$ of distilled water was added to $1 \mathrm{ml}$ of urine from subject $9,1 \mathrm{ml}$ of urine from subject $11,1 \mathrm{ml}$ of urine from subject 11 with urea nitrogen equal to that of subject $9,1 \mathrm{ml}$ of urine from subject 11 with ammonium nitrogen equal to that of subject 9 , and $1 \mathrm{ml}$ of urine from subject 11 with osmolality equal to that of subject 9. Before inoculation of bacteria all samples of urine were adjusted to $\mathrm{pH}$ 5.5. The inoculum was 6 colony-forming units $/ \mathrm{ml}$. Urine from subject 9 and from subject 11 supplemented with urea were bactericidal for strain 13. Urine from subject 11 supported growth of the $E$. coli, and supplementation with sodium chloride or ammonium chloride did not affect the growth-supporting characteristics of urine from subject 11 .

In other experiments urea or ammonium was selectively removed from urine by means of urease or by an inorganic ion exchanger that exchanges sodium for ammonium ions. Urine from subject $1(\mathrm{pH} 5.5,930 \mathrm{mOsm} / \mathrm{kg}$ of water, $1.8 \mathrm{~g}$ of urea $\mathrm{N} / 100 \mathrm{ml}$, and $0.07 \mathrm{~g}$ of ammonium $\mathrm{N} / 100 \mathrm{ml}$ ) that was bactericidal for small inocula of $E$. coli strains 13 and 14 was studied. 5-g of an aluminosodium silicate gel exchanger (Permutit, Folin, Fisher Scientific Co., New York) was added to $10-\mathrm{ml}$ of urine, agitated for $10 \mathrm{~min}$, and the urine was then filtered. Treatment with Permutit resulted in complete removal of ammonium nitrogen, but the urine (after being adjusted to $\mathrm{pH} 5.5$ ) was still bactericidal for $E$. coli strains 13 and 14 .

Urease (Fisher Scientific Co., New York) was deionized by dialysis against distilled water and then suspended in water at a concentration of $2 \mathrm{~g} / 10 \mathrm{ml}$. The urine was adjusted to $\mathrm{pH} 7.0$ by addition of sodium hydroxide and then $0.5 \mathrm{ml}$ of urease suspension was added to $10-\mathrm{ml}$ of urine. The urine was incubated for $30 \mathrm{~min}$ at $50^{\circ} \mathrm{C}$ which converted 1.5 of the $1.8 \mathrm{~g} / 100 \mathrm{ml}$ of urea nitrogen to ammonium nitrogen. The urine was 
then filtered to remove the urease. Treatment with urease increased the osmolality to 1340 and the $\mathrm{pH}$ to 9.0. Even after adjusting the $\mathrm{pH}$ back to 5.5 the urine was still bactericidal for $E$. coli strains 13 and 14. After absorption with $5 \mathrm{~g}$ of Permutit the osmolality remained 1340 and the ammonium nitrogen was reduced to $0.3 \mathrm{~g} / 100 \mathrm{ml}$. Controls were prepared by following the exact same steps, except for using urease that had been inactivated by boiling. The urine to which active urease and then Permutit had been added supported multiplication of small numbers of $E$. coli strains 13 and 14 . The controls were bactericidal for the same inoculum.

Effect of dialyzing urine against various solutions. In other experiments urine was dialyzed at $4^{\circ} \mathrm{C}$ for $24 \mathrm{hr}$ against the following: distilled water; solutions of urea with a urea concentration equal to that of the urine; solutions of ammonium chloride with an ammonium concentration equal to that of the urine; solutions of sodium chloride with osmolality equal to the osmolality of the urine; and mixtures of urea, ammonium chloride, and sodium chloride with ammonium and urea concentration equal to that of the urine, and sodium chloride added to increase the osmolality to equal that of the urine.

After dialysis against water the osmolality was less than $10 \mathrm{mOsm} / \mathrm{kg}$ of water and the urea and ammonium nitrogens were not measurable. Dialysis against urea, ammonium chloride, sodium chloride, or mixtures of these resulted in solutions with urea concentrations, ammonium concentrations, and osmolalities equal to those of the dialyzing fluid. The $\mathrm{pH}$ of the dialyzed urine was always adjusted to equal that of the original urine.

Table II demonstrates a typical experiment in which multiplication of $E$. coli strain 13 was studied in urine from subject 1 with an osmolality of $1006 \mathrm{mOsm} / \mathrm{kg}$ of water, urea nitrogen of 2.0 $\mathrm{g} / 100 \mathrm{ml}$, ammonium nitrogen of $0.1 \mathrm{~g} / 100 \mathrm{ml}$ and $\mathrm{pH}$ of 6 and in dialysates of the urine. This urine was bactericidal for the strain. In this study, 10 colony-forming units suspended in $0.1 \mathrm{ml}$ of trypticase soy broth was inoculated in $1 \mathrm{ml}$ of urine and in $1 \mathrm{ml}$ of each dialysate. As shown in Table II bactericidal activity of the urine was retained after dialysis against urea $(2.0 \mathrm{~g}$ of urea $\mathrm{N} / 100 \mathrm{ml}$ ), urea plus sodium chloride $(2.0 \mathrm{~g}$ of urea $\mathrm{N} / 100 \mathrm{ml}$; osmolality $1006 \mathrm{mOsm} / \mathrm{kg}$ of
TABLE II

Growth-Supporting Qualities of Urine and Dialysates of Urine*

\begin{tabular}{|c|c|}
\hline & $\begin{array}{l}\text { Log in- } \\
\text { crease } \\
\text { after } \\
6 \mathrm{hr} \\
\text { incubation }\end{array}$ \\
\hline \multicolumn{2}{|l|}{ Urine dialyzed against } \\
\hline Water & 4.5 \\
\hline Ureał & $\mathbf{0}$ \\
\hline Ammonium chloride & 4.3 \\
\hline Sodium chloride§ & 2.8 \\
\hline Ureał plus sodium chloride $\$$ & $\mathbf{0}$ \\
\hline Ammonium chloride $\ddagger$ plus sodium chloride $\$$ & 2.7 \\
\hline Ureał plus ammonium chloride $\ddagger$ & $\mathbf{0}$ \\
\hline $\begin{array}{l}\text { Urea } \ddagger \text { plus ammonium chloride } \ddagger \text { plus } \\
\text { sodium chloride } \$\end{array}$ & $\mathbf{0}$ \\
\hline Undialyzed urine & 0 \\
\hline Water & 4.5 \\
\hline
\end{tabular}

* Inoculum was 10 colony-forming units of $E$. coli strain 13 in $0.1 \mathrm{ml}$ of trypticase soy broth.

‡ Same concentration as in the urine.

Added to increase the final osmolality to equal that of the urine.

water $)$, urea plus ammonium chloride $(2.0 \mathrm{~g}$ of urea $\mathrm{N} / 100 \mathrm{ml} ; 0.1 \mathrm{~g}$ of ammonium $\mathrm{N} / 100 \mathrm{ml}$ ), and urea plus ammonium chloride and sodium chloride $(2.0 \mathrm{~g}$ of urea $\mathrm{N} / 100 \mathrm{ml} ; 0.1 \mathrm{~g}$ of ammonium $\mathrm{N} / 100 \mathrm{ml}$; osmolality $1006 \mathrm{mOsm} / \mathrm{kg}$ of water). Bactericidal activity was lost but some inhibition of multiplication was observed following dialysis against sodium chloride (1006 mOsm/ $\mathrm{kg}$ of water) or ammonium chloride and sodium chloride $(0.1 \mathrm{~g}$ of ammonium $\mathrm{N} / 100 \mathrm{ml} ; 1006$ $\mathrm{mOsm} / \mathrm{kg}$ of water). After dialysis against water or ammonium chloride there was no inhibitory activity.

Multiplication of $E$. coli strains in solutions containing sodium chloride, ammonium chloride, and urea

Sodium chloride, urea, and urea plus sodium chloride were added to trypticase soy broth $(3 \mathrm{~g}$ of trypticase soy broth powder $/ 100 \mathrm{ml}$ of water) and to $10 \%$ trypticase soy broth $(0.3 \mathrm{~g}$ of trypticase soy broth powder $/ 100 \mathrm{ml}$ of water) as listed in Table III to prepare solutions with urea concentrations and osmolalities comparable to the urine specimens from the subjects.

Similarly, solutions of ammonium chloride were prepared in trypticase soy broth and in $10 \%$ trypticase soy broth so as to yield ammonium nitrogen concentrations of $0.02,0.06,0.10$, and 
TABLE III

Solutions Made by Adding Sodium Chloride, Urea, and Urea plus Sodium Chloride to Trypticase Soy Broth or 10\% Trypticase Soy Broth in Water

Added to $10 \%$ trypticase soy broth in water $(21 \mathrm{mOsm} / \mathrm{kg}$ of water)

$200,400,600,800,1000,1200$, and $1400 \mathrm{mOsm} / \mathrm{kg}$ of water of $\mathrm{NaCl}$

$1 \mathrm{~g} / 100 \mathrm{ml}$ of urea nitrogen $(360 \mathrm{mOsm} / \mathrm{kg}$ of water)

$1 \mathrm{~g} / 100 \mathrm{ml}$ of urea nitrogen plus $200,400,600,800$, and $1000 \mathrm{mOsm} / \mathrm{kg}$ of water of $\mathrm{NaCl}$

$1.5 \mathrm{~g} / 100 \mathrm{ml}$ of urea nitrogen $(533 \mathrm{mOsm} / \mathrm{kg}$ of water)

$1.5 \mathrm{~g} / 100 \mathrm{ml}$ of urea nitrogen plus $200,400,600$, and 800 $\mathrm{mOsm} / \mathrm{kg}$ of water of $\mathrm{NaCl}$

$2.0 \mathrm{~g} / 100 \mathrm{ml}$ of urea nitrogen $(673 \mathrm{mOsm} / \mathrm{kg}$ of water $)$

$2.0 \mathrm{~g} / 100 \mathrm{ml}$ of urea nitrogen plus $200,400,600$, and $800 \mathrm{mOsm} / \mathrm{kg}$ of water of $\mathrm{NaCl}$

$2.5 \mathrm{~g} / 100 \mathrm{ml}$ of urea nitrogen $(833 \mathrm{mOsm} / \mathrm{kg}$ of water)

$2.5 \mathrm{~g} / 100 \mathrm{ml}$ of urea nitrogen plus 200,400 , and 600 $\mathrm{mOsm} / \mathrm{kg}$ of water of $\mathrm{NaCl}$

Added to trypticase soy broth $(300 \mathrm{mOsm} / \mathrm{kg}$ of water) $200,400,600$, and $800 \mathrm{mOsm} / \mathrm{kg}$ of water of $\mathrm{NaCl}$

$1 \mathrm{~g} / 100 \mathrm{ml}$ of urea nitrogen $(607 \mathrm{mOsm} / \mathrm{kg}$ of water $)$

$1 \mathrm{~g} / 100 \mathrm{ml}$ of urea nitrogen plus $200,400,600$, and 800 $\mathrm{mOsm} / \mathrm{kg}$ of water of $\mathrm{NaCl}$

$1.5 \mathrm{~g} / 100 \mathrm{ml}$ of urea nitrogen $(787 \mathrm{mOsm} / \mathrm{kg}$ of water)

$1.5 \mathrm{~g} / 100 \mathrm{ml}$ of urea nitrogen plus 200, 400, and 600 $\mathrm{mOsm} / \mathrm{kg}$ of water of $\mathrm{NaCl}$

$2.0 \mathrm{~g} / 100 \mathrm{ml}$ of urea nitrogen $(930 \mathrm{mOsm} / \mathrm{kg}$ of water $)$

$2.0 \mathrm{~g} / 100 \mathrm{ml}$ of urea nitrogen plus 200 and $400 \mathrm{mOsm} / \mathrm{kg}$ of water of $\mathrm{NaCl}$

$2.5 \mathrm{~g} / 100 \mathrm{ml}$ of urea nitrogen $(1235 \mathrm{mOsm} / \mathrm{kg}$ of water)

$2.5 \mathrm{~g} / 100 \mathrm{ml}$ of urea nitrogen plus $200 \mathrm{mOsm} / \mathrm{kg}$ of water of $\mathrm{NaCl}$

$0.20 \mathrm{~g} / 100 \mathrm{ml}$. In a manner similar to Table III, sodium chloride was added to aliquots of each of the ammonium chloride solutions to provide increasing osmolalities in stepwise increments of 200 $\mathrm{mOsm} / \mathrm{kg}$ of water.

Aliquots of all solutions were adjusted to $\mathrm{pH}$ 5.0, 5.5, 6.0, and 6.5. Multiplication of E. coli strains 9,13 , and 14 was studied in $1 \mathrm{ml}$ of each solution at each of the four $\mathrm{pH}$ 's after inoculation of 3-40 colony-forming units $/ \mathrm{ml}$ suspended in $0.1 \mathrm{ml}$ of water. All solutions were heated to $37^{\circ} \mathrm{C}$ before addition of the bacterial inoculum and maintained at $37^{\circ} \mathrm{C}$ for the duration of the experiment.

When multiplication of bacteria occurred in a solution it was usually most rapid at $\mathrm{pH} 6.5$,

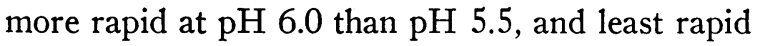
at $\mathrm{pH}$ 5.0. These relationships were more consistent in the trypticase soy broth solutions than in the $10 \%$ broth solutions perhaps related to the better buffering capacity of the undiluted broth and the resultant greater stability of $\mathrm{pH}$ during growth of bacteria.

Solutions of ammonium chloride were not inhibitory for multiplication of bacteria, as compared with broth controls. With addition of sodium chloride to ammonium chloride inhibitory activity appeared, but was no more than was observed in solutions of sodium chloride alone at the same osmolalities. Solutions of sodium chloride at high osmolalities and solutions of urea demonstrated antibacterial activity.

Fig. 7 shows results after $6 \mathrm{hr}$ of incubation of E. coli strain 13 in solutions of sodium chloride, urea, and urea plus sodium chloride made in $10 \%$ trypticase soy broth at a $\mathrm{pH}$ of 6.0 . Multiplication was optimal in sodium chloride solutions at osmolalities between 200 and $600 \mathrm{mOsm} / \mathrm{kg}$ of water. At an osmolality above 600 the rate of multiplication decreased. Multiplication was markedly inhibited in all of the urea solutions without added sodium chloride (represented by the first point on each of the urea curves in Fig. 7). With addition of sodium chloride to the solutions of urea, the rate of multiplication of bacteria tended to increase and did not fall again until osmolalities over $1000 \mathrm{mOsm} / \mathrm{kg}$ of water were achieved. As the concentration of urea increased, the rate of multiplication decreased. For example, as shown in Fig. 7, peak multiplication in $1 \mathrm{~g} / 100 \mathrm{ml}$ of urea nitrogen was a $4.1 \mathrm{log}$ increase (at 560 $\mathrm{mOsm} / \mathrm{kg}$ of water), as compared with only a $2.7 \mathrm{log}$ increase in $1.5 \mathrm{~g} / 100 \mathrm{ml}$ of urea nitrogen (at $1133 \mathrm{mOsm} / \mathrm{kg}$ of water).

Similar results were observed in the solutions in trypticase soy broth as shown in Fig. 8. The main difference is that the first points on the urea curves represent solutions that contain 300 $\mathrm{mOsm} / \mathrm{kg}$ of water of trypticase soy broth. Therefore in terms of osmolality other than that contributed by urea, these points are comparable to the second and third points on the urea curves in Fig. 7.

Results similar to these were obtained with $E$. coli strains 9 and 14, except that inhibition was more marked with strain 14 than with strain 13 and less marked with strain 9 than it was with strain 13. It is apparent from these data that over the ranges of ammonium concentrations, urea con- 


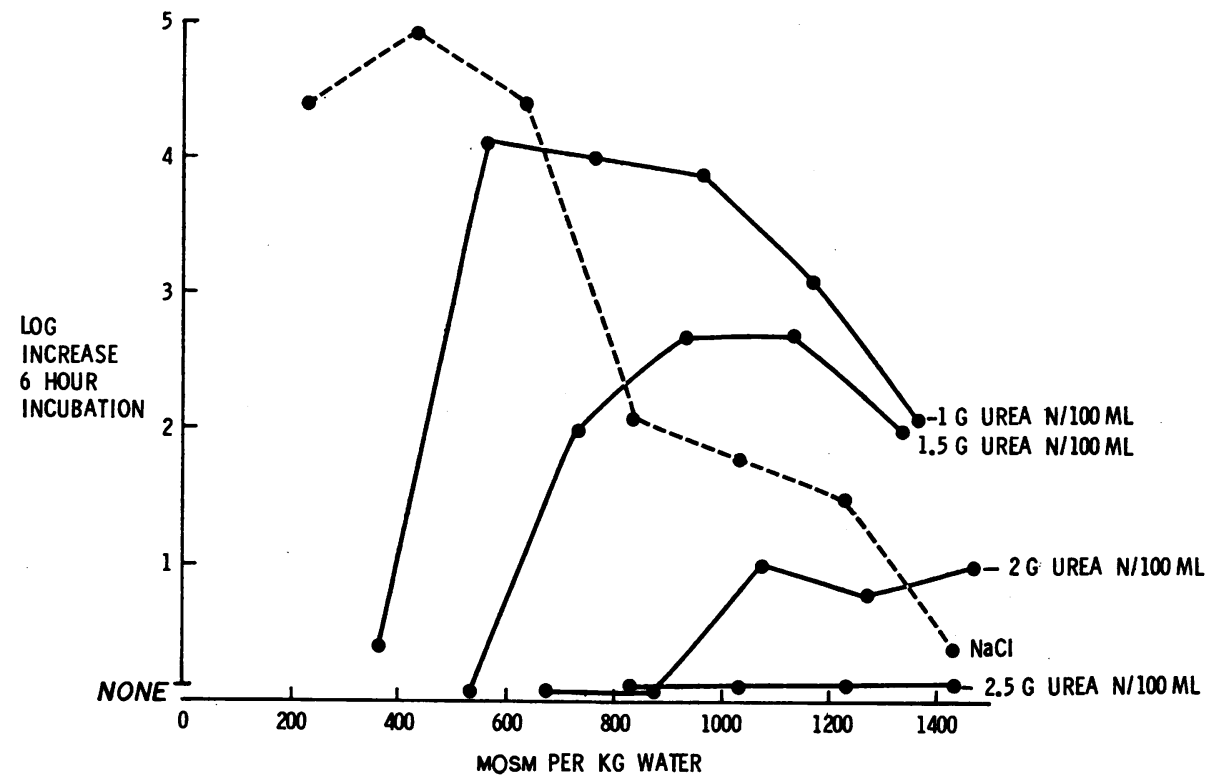

FIgURE 7 Increase in numbers of E. coli strain 13 in solutions of sodium chloride, urea, and urea and sodium chloride in $10 \%$ trypticase soy broth at $\mathrm{pH} 6.0$. The inoculum was 10 colonyforming units $/ \mathrm{ml}$.

centrations, and osmolalities found in the subjects in this study, the rate of multiplication of bacteria is much more a function of urea concentration than that of ammonium concentration or osmolality. Fig. 9 demonstrates the results from Fig. 7
(E. coli strain 13 in solutions in $10 \%$ trypticase soy broth at $\mathrm{pH} 6.0$ ) plotted with urea concentration on the abscissa rather than with osmolality. It is clear that multiplication was about the same in a urea solution despite variations in osmolality

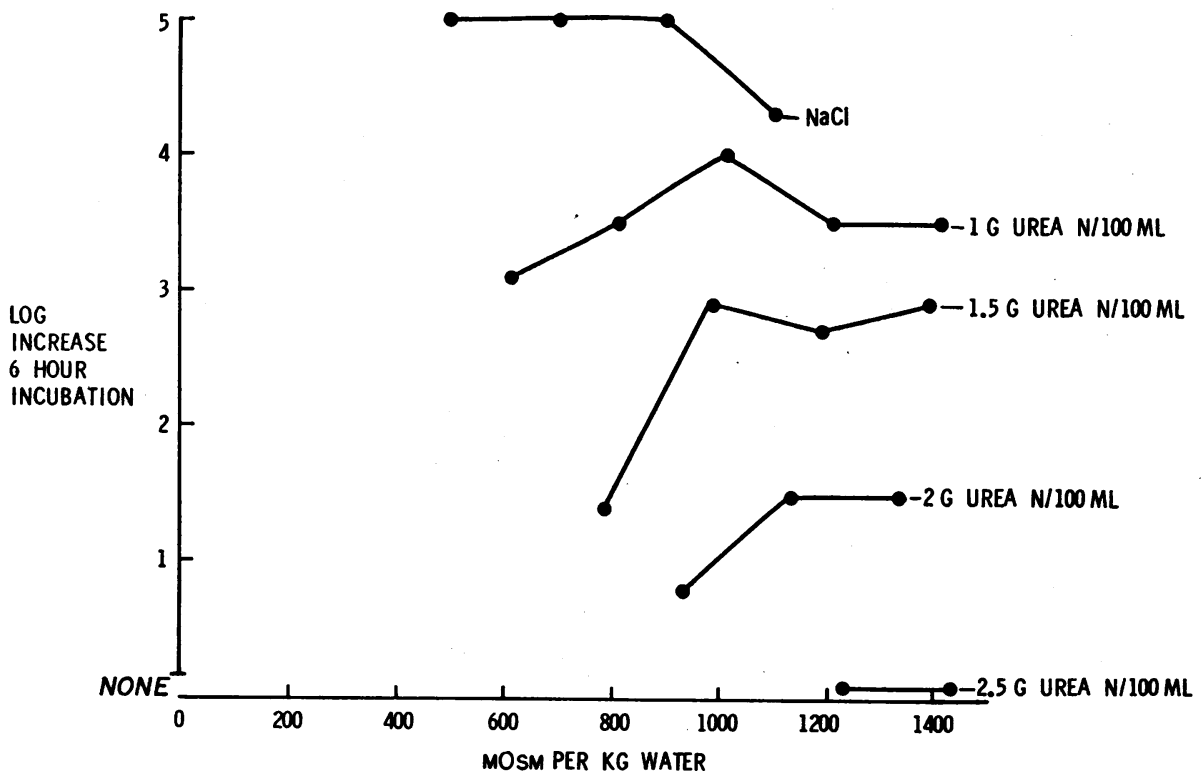

FIGURE 8 Increase in numbers of $E$. coli strain 13 in solutions of sodium chloride, urea, and urea and sodium chloride in trypticase soy broth at $\mathrm{pH} \cdot 6.0$. The inoculum was 10 colonyforming units $/ \mathrm{ml}$. 


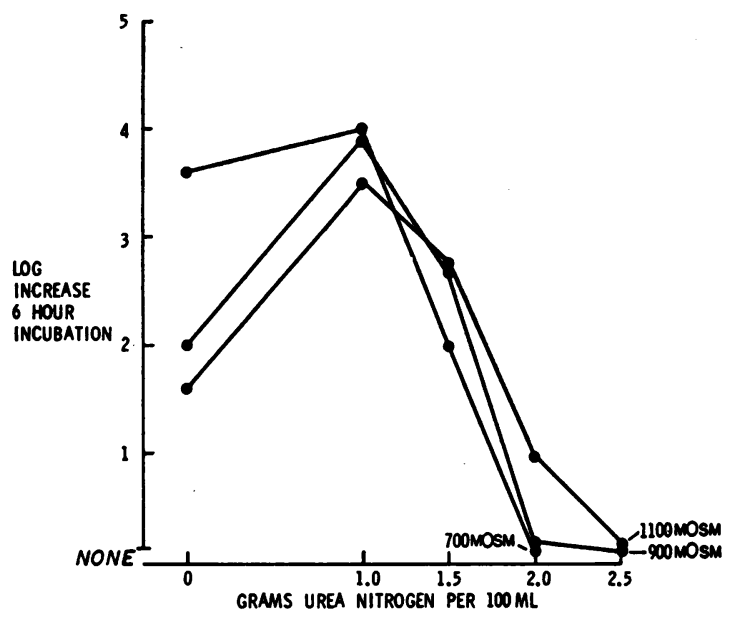

Figure 9 Increase in numbers of $E$. coli strain 13 in solutions of sodium chloride, urea, and urea and sodium chloride in $10 \%$ trypticase soy broth at $\mathrm{pH} 6.0$. The data are derived from Fig. 7. The inoculum was 10 colony-forming units $/ \mathrm{ml}$.

from 700 to $1100 \mathrm{mOsm} / \mathrm{kg}$ of water. Fig. 10 shows the data from Fig. 8 ( $E$. coli strain 13 in solutions in trypticase soy broth at $\mathrm{pH}$ 6.0) plotted in a similar fashion; in addition the data are plotted for $E$. coli strain 13 in solutions in trypticase soy broth at $\mathrm{pH}$ 5.0. It is clear that similar to solutions in $10 \%$ trypticase soy broth,

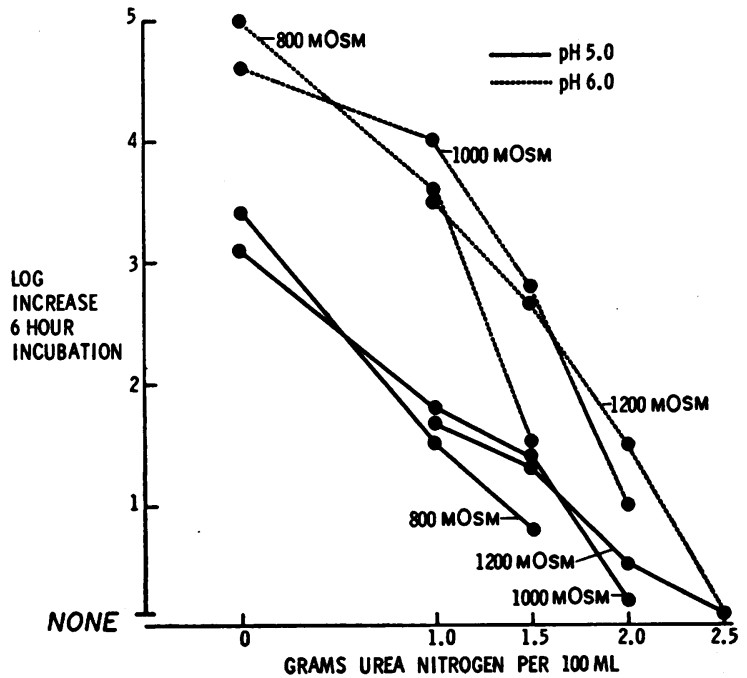

FIGURE 10 Increase in numbers of $E$. coli strain 13 in solutions of sodium chloride, urea, and urea and sodium chloride in trypticase soy broth at $\mathrm{pH} 5.0$ and 6.0. The data at $\mathrm{pH} 6.0$ are derived from Fig. 8. The inoculum was 10 colony-forming units $/ \mathrm{ml}$.
TABLE IV

Effect of Ingestion of Urea on $p H$, Osmolality, Urea, and Ammonium

\begin{tabular}{lcc}
\hline & $\begin{array}{c}\text { Before } \\
\text { inges- } \\
\text { tion of } \\
\text { urea }\end{array}$ & $\begin{array}{c}\text { After } \\
\text { inges- } \\
\text { tion of } \\
10 \mathrm{~g} \text { of } \\
\text { urea }\end{array}$ \\
\hline Subject 1 & & \\
$\mathrm{pH}$ & 5.7 & 5.7 \\
Osmolality, mOsm/kg of water & 1100 & 1070 \\
Urea, $\mathrm{g}$ of urea $\mathrm{N} / 100$ ml & 1.4 & 2.1 \\
Ammonium, $\mathrm{g}$ of ammonium $\mathrm{N} / 100 \mathrm{ml}$ & 0.06 & 0.09 \\
Subject 4 & & \\
$\mathrm{pH}$ & 5.4 & 5.4 \\
Osmolality, mOsm/kg of water & 813 & 1020 \\
Urea, $\mathrm{g}$ of urea $\mathrm{N} / 100$ ml & 1.1 & 1.8 \\
Ammonium, $\mathrm{g}$ of ammonium $\mathrm{N} / 100 \mathrm{ml}$ & 0.05 & 0.09 \\
Subject 5 & & \\
pH & 6.0 & 5.6 \\
Osmolality, mOsm/kg water & 917 & 886 \\
Urea, $\mathrm{g}$ urea $\mathrm{N} / 100$ ml & 1.1 & 1.6 \\
Ammonium, $\mathrm{g}$ of ammonium $\mathrm{N} / 100 \mathrm{ml}$ & 0.09 & 0.06 \\
\hline
\end{tabular}

rate of multiplication in solutions in trypticase soy broth was more a function of urea concentration than of osmolality. Furthermore the inhibitory effects of urea were much more marked at $\mathrm{pH} 5.0$ than at $\mathrm{pH} 6.0$.

Effect on antibacterial activity of urine of ingestion of exogenous urea

Three subjects, $(1,4$, and 5$)$ each ingested $10 \mathrm{~g}$ of urea (in capsules) before going to sleep. The first voided urine in the morning was collected and compared with the first voided morning urine from the previous day. Table IV shows the $\mathrm{pH}$, osmolality, urea concentration, and ammonium concentration of each of the urines. In each subject the urea concentration was increased by at least $0.5 \mathrm{~g}$ of urea nitrogen $/ 100 \mathrm{ml}$ of urine after ingestion of urea. As shown in Fig. 11, first voided morning urine collected after ingestion of urea was more inhibitory for the strains of $E$. coli tested than was first voided morning urine collected before ingestion of urea. In fact, all three urines collected after ingestion of urea were bactericidal for E. coli strains 13 and 14 .

\section{DISCUSSION}

In discussing the kinetics of urinary tract infection O'Grady and Cattell $(4,19)$ emphasized as a host defense mechanism the importance of the mechanical effect of urine flow in diluting and 


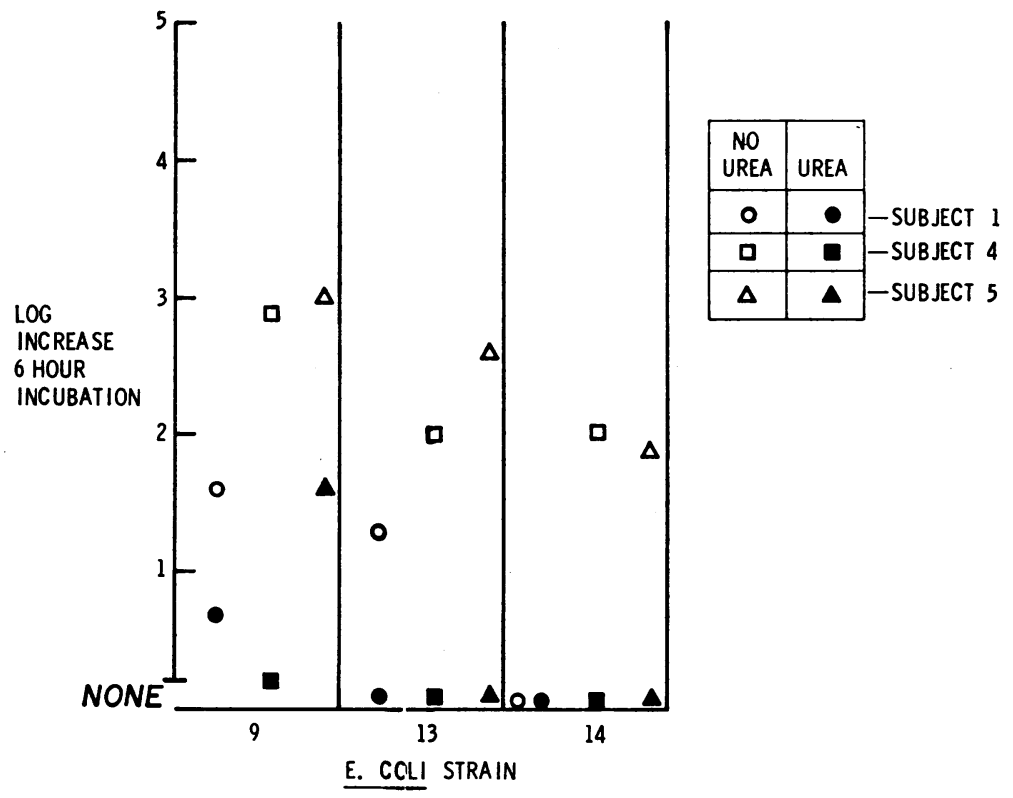

FIGURE 11 Increase in numbers of $E$. coli strains 9,13 , and 14 in urine from Subjects 1, 4, and 5 before and after ingestion of $10 \mathrm{~g}$ of urea. The inocula were 3-40 colony-forming units $/ \mathrm{ml}$. removing bacteria from the urinary tract. They also assumed that the common urinary pathogens multiply in urine at about the same rate as in artificial media. If, as shown in the present study, urine from normal individuals is often inhibitory and sometimes bactericidal for growth of these organisms, then a slow rate of bacterial multiplication in the urine combined with voiding would act as an effective antibacterial defense mechanism in the human bladder.

In the present studies there were marked differences in susceptibility of various strains of $E$. coli to the inhibitory and bactericidal activity of urine. Furthermore, there was a suggestion that when very small inocula of $E$. coli were used (i.e., 3-40 colony-forming units), E. coli strains isolated from urine multiplied more rapidly in urine than $E$. coli strains isolated from stool.

The poor growth-supporting qualities of the urine samples studied were not related to a lack of nutrient material, as addition of broth to urine did not eliminate the inhibitory activity. The fact that dilution of urine in water or dialysis of urine against water eliminated inhibitory activity is further evidence that the inhibitory activity was not due to a simple lack of nutrient material.

Gamma-A immunoglobulins have been isolated from normal human urine in small amounts (20) (i.e., an average of $1.1 \mathrm{mg} /$ day), but have not been demonstrated to have antibacterial activity.
The observation that the antibacterial activity of urine against a bacterial strain could not be removed by absorption with bacterial vaccine prepared from the same strain provides evidence against the role of antibody in the antibacterial activity of urine. Additional evidence against antibody or any other protein serving as the major determinant are the facts that the antibacterial activity of urine could not be destroyed by removing protein by ultrafiltration, by column chromatography, or by boiling, and that it could be eliminated by dialysis against water. Furthermore, the protein-containing portion of the urine separated by chromatography had no antibacterial activity.

Urine $\mathrm{pH}$ was shown to be an important variable. As the $\mathrm{pH}$ was adjusted upward from 5.0 to 6.5 , the inhibitory activity of the urine decreased. These results are similar to those of others (10 15). Kass and Ziai (8) described an inhibitor found in urine of some normal individuals that was most active at $\mathrm{pH} 5.0$ and that lost much of its activity as the $\mathrm{pH}$ of the urine was raised. This inhibitor was nonvolatile, alcohol-soluble and ether-insoluble, and was thought to be a weakly ionizable acid. The inhibitory activity of the urine in the present study was most active at $\mathrm{pH} 5.0$ but was also active at $\mathrm{pH} 5.5$ and 6.0, and was demonstrated mainly in concentrated urines. This inhibitory activity was shown to be due mainly 
to the presence of urea. It is of interest that urea is nonvolatile, ethyl alcohol-soluble and ethyl ether-insoluble. Furthermore, the weakly ionizable acids discussed by Bodel, Cotran, and Kass (9) such as hippuric acid, mandelic acid, acetic acid, and beta-hydroxybutyric acid are generally as soluble in ethyl ether as in ethyl alcohol (21). It is possible that the $\mathrm{pH}$-dependent factor of Kass and Ziai in normal urine may have been urea.

Antibacterial activity of urine in the present study was not correlated to the total concentration of organic acids. However, the titration of total organic acids probably reflects a mixture of organic acids with different $\mathrm{pK}$ values. As the concentrations of these different acids vary with diet and fluid intake, it is likely that organic acids play a more important role in the antibacterial activity of urine than indicated by the present study.

It is clear from the study of Bodel, et al. (9) that high concentrations of organic acids in urine are inhibitory for growth of bacteria. These investigators showed that $0.02 \mathrm{~m}$ hippuric acid was bacteriostatic in vitro at $\mathrm{pH} 5.0$ for a strain of $E$. coli. This concentration of hippuric acid was achieved in urine only in subjects ingesting large volumes of cranberry juice which raised the daily urinary excretion of organic acid to $90 \mathrm{mEq}$. Without ingestion of cranberry juice the subjects excreted $50-75 \mathrm{mEq}$ of organic acid daily and the urine was not bacteriostatic. In the present study the daily excretion of organic acid was below 75 $\mathrm{mEq}$ in all subjects and none were drinking cranberry juice.

The osmolalities of urines in the present study were considerably higher than those observed by Asscher et al. (15). They found that over half of the population studied had early morning urine osmolalities of $600 \mathrm{mOsm} / \mathrm{kg}$ of water or less. In the present study (and in many additional determinations by this investigator), first voided morning urine from normal individuals always has an osmolality more than $600 \mathrm{mOsm} / \mathrm{kg}$ of water. Furthermore, Jacobson et al. (22) demonstrated that following overnight fluid and food deprivation for $14 \mathrm{hr}$, normal individuals should have urine osmolalities of $850 \mathrm{mOsm} / \mathrm{kg}$ of water or more. One reason for the lower osmolalities in the studies by Asscher et al. may be related to differences in the population studied. Asscher et al. did not exclude patients who may have had renal dis- ease; furthermore they studied an older population, $16-65 \mathrm{yr}$, as compared with $5-35 \mathrm{yr}$ in the present studies. Other possible explanations for differences in osmolalities are differences in diet (e.g., differences in protein and sodium chloride intake) and differences in fluid intake.

In the present study, the inhibitory quality of urine samples was directly correlated with osmolality, with urea content, and with ammonium concentration. As about one-half of the osmolality in the urines studied was related to the urea present, it is clear that urines with high osmolality will also usually have high urea concentrations.

Kaitz (14) also noted more inhibitory activity in concentrated urines and stated that inhibition in concentrated urines that is $\mathrm{pH}$-nondependent appeared to be due to urea. No methods or experimental data were given. No studies have attempted to correlate endogenous urea concentration of urine to antibacterial activity and to separate the effects of osmolality from the effects of urea concentration, ammonium concentration, and organic acid concentration.

There are previous studies suggesting that urea may contribute to antibacterial activity of urine. Hain (23) demonstrated that urine from dogs receiving a high protein diet (meat) had antibacterial activity, but that the antibacterial activity was lost when the diet was changed to a low protein diet (no meat). Schlegel, Cuellar, and O'Dell (24) found that urea in nutrient broth at $\mathrm{pH}$ 7.0-7.1 has antibacterial activity in concentrations of $1-4 \mathrm{~g} / 100 \mathrm{ml}(0.48-1.9 \mathrm{~g}$ of urea nitrogen/100 $\mathrm{ml}$ ). Neter and Clark (16) showed that addition of $3.1-6.3 \mathrm{~g} / 100 \mathrm{ml}$ of urea $(1.5-3.0 \mathrm{~g}$ of urea nitrogen $/ 100 \mathrm{ml}$ ) to human urine markedly increased antibacterial activity. Finally Schlegel, Raffii, Flinner, and O'Dell (25) and O'Dell, Brazil, and Schlegel (26) were able to decrease the incidence of urinary tract infection in dogs and rats by administering urea after introduction of bacteria into the urinary tract.

The results of the present study provide evidence for the role of urea in human urine as an antibacterial agent. They also suggest that within the ranges of concentration commonly achieved in human urine. antibacterial activity is more a function of urea content than of osmolality, organic acid concentration, or ammonium concentration. 
A solution of urea and sodium chloride in $10 \%$ trypticase soy broth had similar growth-supporting or inhibiting characteristics for strains of $E$. coli as a urine specimen with the same urea concentration, osmolality, and $\mathrm{pH}$. It was therefore possible to predict the antibacterial activity of a urine specimen, if the urea content, osmolality, and $\mathrm{pH}$ were known.

Prostatic fluid in dogs (27) and prostatic fluid and semen in man (28) are inhibitory for E. coli strains. The antibacterial activity of urine observed in the present study cannot be completely explained by presence of prostatic fluid, as urine from females was also found to be antibacterial. (In fact, the most antibacterial urine studied was that of a female, subject 6.) However, the possibility cannot be excluded that, in some of the males in the present study, prostatic fluid or semen may have contributed to the antibacterial activity of the urine.

Asscher et al. (15) observed that urine from females tended to support multiplication of $E$. coli better than urine from males, and Asscher et al. and Roberts and Beard (29) showed that urine from pregnant females supported multiplication of $E$. coli better than urine from nonpregnant females. These differences were felt to be related to the fact that the $\mathrm{pH}$ of urine from males was lower than the $\mathrm{pH}$ of urine from females, which in turn was lower than the $\mathrm{pH}$ of urine from pregnant females (15). Urea concentrations were not determined and differences in urea concentrations may have explained some of the differences in growth-supporting ability of the urines.

The results of the present study and those of Roberts and Beard and Asscher et al. suggest that antibacterial activity of human urine may be an important factor in preventing urinary tract infection and may also help to select bacterial strains when infection does occur.

\section{ACKNOWLEDGMENTS}

The author is grateful to Dr. Marvin Turck for serotyping the $E$. coli strains and to Miss Judith Gips for technical assistance.

Dr. Kaye received a Career Scientist Award from the Health Research Council of the City of New York (contract I-489). This investigation was supported by the Health Research Council of the City of New York under contract U-1107, by grants AI 07581, AI 05940, HE 03479, and training grant T1 AI255 from the U. S. Public Health Service.

\section{REFERENCES}

1. Kaye, D. 1967. Antibacterial activity of human urine. J. (lin. Invest. 46: 1078. (Abstr.)

2. Kass, E. H. 1956. Asymptomatic infections of the urinary tract. Trans. Assoc. Am. Physicians. 69: 56.

3. Cox, C. E., and F. Hinman, Jr. 1961. Experiments with induced bacteriuria, vesicle emptying and bacterial growth on the mechanism of bladder defense to infection. J. Urol. 86: 739.

4. O'Grady, F., and W. R. Cattell. 1966. Kinetics of urinary tract infection. I. Upper urinary tract. Brit. J. Urol. 38: 149.

5. Davis, E. G., and R. F. Hain. 1918. Urinary antisepsis. The antiseptic properties of normal dog urine. J. Urol. 2: 309.

6. Clark, A. L. 1931. Escherichia coli bacilluria under ketogenic treatment. Proc. Staff Meetings Mayo Clinic. 6::605.

7. Helmholz, H. F. 1931. The ketogenic diet in the treatment of pyuria of children with anomalies of the urinary tract. Proc. Staff Meetings Mayo Clinic. 6: 609.

8. Kass, E. H., and M. Ziai. 1958. Methionine as a urinary tract antiseptic. Antibiot. Ann. 1957-1958. 80.

9. Bodel, P. T., R. Cotran, and E. H. Kass. 1959. Cranberry juice and the antibacterial action of hippuric acid. J. Lab. Clin. Med. 54: 881.

10. Shohl, A. T., and J. H. Janney. 1917. The growth of Bacillus coli in urine at varying hydrogen ion concentrations. J. Urol. 1: 211.

11. Yeaw, R. C. 1940. The effect of $\mathrm{pH}$ on the growth of bacteria in urine. J. Urol. 44: 699.

12. Kass, E. H. 1960. The role of asymptomatic bacteriuria in the pathogenesis of pyelonephritis. In Biology of Pyelonephritis. E. L. Quinn and E. H. Kass, editors. Little, Brown and Company, Boston. 399.

13. Mou, T. W. 1962. Effect of urine $\mathrm{pH}$ on the antibacterial activity of antibiotics and chemotherapeutic agents. J. Urol. 87 : 978.

14. Kaitz, A. L. 1964. Dynamics of bacteriuria. In Antimicrobial Agents and Chemotherapy-1963. J. C. Sylvester, editor. American Society for Microbiology, Ann Arbor. 613.

15. Asscher, A. W., M. Sussman, W. E. Waters, R. H. Davis, and S. Chick. 1966. Urine as a medium for bacterial growth. Lancet. 2 : 1037.

16. Neter, E. R., and P. Clark. 1944. The combined antimicrobial activity of urea and sulfathiazole in urine. J. Urol. 51 : 101.

17. Jackson, G. G., and H. G. Grieble. 1957. Pathogenesis of renal infection. Arch. Internal Med. 100: 692.

18. Van Slyke, D. D., and W. W. Palmer. 1920. Studies of acidosis. XVI. The titration of organic acids in urine. J. Biol. Chem. 41 : 567.

19. O'Grady, F., and W. R. Cattell. 1966. Kinetics of urinary tract infection. II. The bladder. Brit. $J$. Urol. 38: 156.

20. Bienenstock, J., and T. B. Tomasi, Jr. 1967. Secretory $\gamma \mathrm{A}$ in urine. Clin. Res. 15: 292. (Abstr.)

21. Hodgman, C. D., R. C. Weast, and S. M. Selby. 1961. 
Handbook of Chemistry and Physics. Chemical Rubber Publishing Company, Cleveland. 43rd edition.

22. Jacobson, M. H., S. E. Levy, R. M. Kaufman, W. E. Gallinek, and O. W. Donnelly. 1962. Urine osmolality. A definitive test of renal function. Arch. Internal Med. 110: 83.

23. Hain, R. F. 1920. Antiseptic properties of normal dog urine as influenced by diet. J. Urol. 4: 177.

24. Schlegel, J. U., J. Cuellar, and R. M. O'Dell. 1961. Bactericidal effect of urea. J. Urol. 86: 819.

25. Schlegel, J. U., P. Raffii, R. Flinner, and R. M. O'Dell. 1964. Studies in acute experimental pyelonephritis. Invest. Urol. 1: 362.
26. O'Dell, R. M., W. O. Brazil, and J. U. Schlegel. 1967. Effectiveness of urea in prophylaxis of experimentally induced bacteriuria in rats. J. Urol. 97: 145.

27. Youmans, G. P., J. Liebling, and R. Y. Lyman. 1938. The bactericidal action of prostatic fluid in dogs. J. Infect. Diseases. 63: 117.

28. Taylor, P. W., and H. R. Morgan. 1952. Antibacterial substances in human semen and prostatic fluid. Surg. Gynecol. Obstet. 94: 662.

29. Roberts, A. P., and R. W. Beard. 1965. Some factors affecting bacterial invasion of bladder during pregnancy. Lancet. 1: 1133 . 